\title{
ОПТИМИЗАЦИЯ ЛАБОРАТОРНОЙ ТЕХНОЛОГИИ ПОЛУЧЕНИЯ О-ПРОПИЛОКСИМ-N- ПРОПОКСИБАКТЕРИОПУРПУРИНИМИДА
}

\author{
И.С. Петрова, Р.Н. Соловьев, Н.В. Суворов, М.Н. Усачев, \\ А.Ф. Миронов, М.А. Грин \\ МИРЭА - Российский технологический университет, \\ 119571, Россия, г. Москва, пр. Вернадского, 86, стр. 6.
}

DOI: 10.19163/MedChemRussia2021-2021-408

E-mail: irinptrt@mail.ru

Целью настоящей работы является оптимизация синтеза 0-пропилоксим$\mathrm{N}$-пропоксибактериопурпуринимида (дипропокси-БПИ) - перспективного фотосенсибили-затора для ФДТ опухолевых новообразований.

Дипропокси-БПИ был получен модификацией бактериохлорофилла а (Бхл а), выделенного из биомассы пурпурных бактерий Rhodobacter Sphaeroides [1]. Все реакции проводились с использованием коммерчески доступных реактивов, при защите от прямого света и в условиях инертной атмосферы. Электронные спектры получены на спектрофотометре Ultrospec 2100 pro (США) в кварцевых кюветах толщиной 10 мм. Все соединения были анализированы с использованием ультравысокоэффективной жидкостной хроматографической системы «Dionex UltiMate RS 3000», совмещенной с гибридным масс-спектрометром высокого разрешения «Q-Exactive».

Был выбран оптимальный экстрагент для выделения Бхл а из биомассы бактерий Rhodobacter Sphaeroides: система изопропанол : этанол (объёмное соотношение 1:1), позволяющая сократить время экстракции с 48 до 2 часов. Окисление Бхл $а$ в бактериопурпурин чистым кислородом показало сокращение времени окисления до 1-1,5 часов.

Таким образом, данные усовершенствования потенциально позволят существенно снизить время синтеза и стоимость активной фармацевтической субстанции на основе дипропокси-БПИ.

\section{Литература}

[1] Миронов А.Ф., Грин М.А. Сенсибилизаторы бактериохлоринового ряда: перспективы использования в фотодинамической терапии, Вестник МИТХТ. 2006, №4, С. 5-28. 